\title{
Histochemical demonstration of protein concentration in intestinal tissue of coccidiosis infected broiler chicks treated with Mercurius corrosivus
}

\author{
Naphade S. T. 四
}

Received: 16.08.2020

Revised: 03.10.2020

Accepted: 09.11.2020

\begin{abstract}
The present investigation includes the study of protein concentration in intestinal tissue of coccidiosis infected broiler chicks orally inoculated by the infection of Eimeria tenella sporulated oocysts and treated with Mercurius corrosivus by using the methods of histochemical techniques. The treatment of homoeopathic medicine Mercurius corrosivus was administered to the coccidiosis infected group of broiler chicks.For the study of protein concentration in intestinal tissue of the coccidiosis infected and non-infected broiler chicks, the histochemical technique was used. Histochemical study indicates that the presence of different concentration of protein content found in the intestinal tissue of the broiler chicks.Intestinal tissue of all the chicks of different groups have presence of protein content in variable concentrations. It is also observed that the presence of protein concentration was variable in different region and shows different traces like minimum, medium and maximum amount of protein content found in different region of the intestinal tissue.The amount of protein concentration was observed high in group B(INC) in comparison to the other group of chicks observed during the experimental period. The concluded results of the study by using histochemical techniques shows that the protein concentration in the intestinal tissue is demonstrated by the variable staining reaction. The concentration of protein content is maximum in the parasitic stages showing the utilization of the protein from the host tissue. Whereas the infected and treated group with homoeopathic medicine Mercurius corrosivus also showed variable staining reaction according to the presence of protein in the intestinal tissue.
\end{abstract}

Key Words: Broiler chicks, Coccidiosis, Histochemical technique, Intestinal tissue, Mercurius corrosivus, Protein

\section{Introduction}

In India the fowl production company commenced as the family type in the rural areas as a subsidiary occupation to reap some extra profits however in the private sector the poultry end up management intensive enterprise which offers excessive profits and emerged as an industry in many of the smaller poultry devices in the recent years. Rural areas are genuinely based totally upon the local fowls. Such units generally have a very constrained range of birds which varies from 20 to 100 and are viewed as capacity to complement the household income. Such smaller units are run via agricultural landless labour, the smaller and marginal dryland farmers etc. This unit depends in reality upon neighborhood material, often the bird surely scavenging on the feed regionally handy in the rural areas. The birds are normally reared in the rural areas. The birds are commonly hard and are tolerant to quite a few diseases. Poultry birds are a domestic species of Author's Address

Department of Zoology, Yeshwantrao Chavan Arts, Commerce and Science College, Sillod, Dist. Aurangabad, M.S. (India)

E-mail.: drsudhirn11@gmail.com avian group of animal kingdom. Poultry birds particularly broiler chicks and backyard chicks are reared by the farmers as allied agricultural business for improving the economic status of the farmer as well as provide protein rich food to the rural population. During the rearing period farmers face many health related problems of chicks. Disease occurrence is the major problems in poultry faced by farmers in various region in India. These problems are related to various issues like differences in climate conditions in different region, also types of management system.

Most of parasitic diseases occurred in broiler chicks. Protozoan disease of poultry particularly coccidiosis is most dangerous and significant disease which causes loss to the farmers and is related to the methods of management in poultry farming.Coccidiosis is the major disease of broiler chicks, particularly it affects the early aged broiler chicks. Coccidiosis disease is not only the major disease but the rate of mortality is too high.During management of poultry industry, if proper action is not taken against the disease, it can destroy the total 
poultry industry due to high mortality. Ultimately it affects the total economic loss of the poultry industry. There are quite a few species of genus Eimeria, a sporozoan parasite which have many fold results on broiler production. The E. tenella, found all over the country creates the caecal coccidiosis in chicken inflicting sizable economic losses which are basically due to excessive rate of morbidity and mortality, terrible weight gain and feed conversion. This is one of the most serious and steady problems in poultry, particularly tropical nations like India. Coccidiosis is one of the most necessary and important disorder in broiler birds, (Pellerdy, 1974) and most essential causes of financial losses within the poultry industry, (Williams et al., 1999). This sickness is induced by way of Eimeria parasites, which infect epithelial cells of the gut of the birds.A few anticoccidial compound or allopathic medicines are accessible, (Singh et al., 1982) for the control of caecal coccidiosis in poultry, which is welcomed on by method of microbe Eimeria tenella, larger part of such medicines neglect to test totally the malady, particularly in the event of consolidated disease and, for example, a final product there will be development of safe hints of the protozoan parasites, (Gill and Bajwa, 1979).The pharmaceutical companies from Homoeopathic remedy are diverting their attention to find out the active principles from herbs, minerals and organic matters, (Homoeopathic drug) and patent the same. There has been renewed thrust all over the world in the direction of developing ecofriendly homoeopathic drug from such remedies as alternatives to the chemical drugs, (Farrington, 1989).Homoeopathic remedies can therefore be used in the confidence that, even if the wrong remedy is chosen, while it will achieve no cure it will do no harm, (Day Christopher;1988). The remedy being only energy, than fades and the body is cured of its disease process. The symptoms then cease. Homoeopathic remedies tested, on the same human basis, in animals. It is very sensible choice of treatment in animals whenever the similia principle can be established. The use of some homoeopathic drug on different diseases of poultry is given by (Narhari, 1996). For the effective remedy and manage of coccidiosis and to fight the development of drug resistance, new types of anticoccidial medicines are being synthetic and tried every so often. Use of some homoeopathic medicine to fight different illnesses in animals (Madrewar,1996). The importance of homoeopathic medicine and their powerful sustainable use apart from in people is defined nicely by using (Naveen; 2005). Many authors have studied the histopathology and histochemistry of different birds, (Hodges, 1974). Al-Saffar et al. (2016) reported that the submucosal connective tissue revealed positive reaction for mercury bromophenol blue technique in birds.In this mild at some point of the existing study, the homoeopathic medication Mercurius corrosivus $1 \mathrm{M}$ potency become tried towards experimental coccidiosis of broiler chicks. Its effect was analyzed on one of the parameters, eg. Protein concentration in intestinal tissue by using histochemical technique.

\section{Material and Methods}

For conducting the experiment a day old, one hundred and twenty broiler chicks vaccinated against Marek's disease were brought from a hatchery. All the broiler chicks were reared up to six weeks in the Laboratory Animal House under managemental conditions as described by (Narhari, 1996). The experimental rearing house is made completely sterilized before housing of chicks.During the experiment the broiler chicks had been maintained in a condition of non-coccidia climate with coccidiostat unfastened starter ration up to the pre weeks of age accompanied through finisher ration for subsequent three weeks with unfastened access to regular ingesting water.Mercurius corrosivus is a powerful remedial agent in disease of the intestinal tract, (Chaudhari, 1990). By taking into consideration the basic principle of homoeopathy let like be treated by like and with minimal dose, the drug Mercurius corrosivus is selected.For comparative study here the reference anticoccidial drug, Amprolium (Merck) is selected and used in experimentation.

For the experimentation the broiler chicks already reared up to three weeks of age were allotted at equal into four groups A to D (30 each)marked and banded the broiler chicks individually from each group. The experimental group A to D are kept separately in the experimental house, managed and fed by following the routine managemental practice. The chicks from Group $\mathrm{A}(\mathrm{NHC})$ served as 
non-infected healthy chicks. The chicks from group B to D was infected with 50,000 sporulated oocysts of E.tenella on $23^{\text {rd }}$ day of age. The chicks from Group B(INC) were infected non-treated and the chicks from group $\mathrm{C}$ (IAC) were infected and treated with reference anticoccidial drug Amprolium $(0.1 \%)$ dose after $3^{\text {rd }}$ day of postinfection for three days through drinking water, while the chicks from group D (IMC) were infected and treated with liquid dilutions of homoeopathic medicine Mercurius corrosivus 1 M potency after $3^{\text {rd }}$ day of post infection for three days through drinking water. The chicks from each group were observed up to the age of sixth week. For histochemical technique, the intestine of the dead and sacrificed (treated and untreated) chicks was subjected to demonstration of protein content. For demonstration of protein contents suitable pieces of intestine were collected and fixed in Carnoy's fluid, (Singh et al., 1997). The tissues had been processed to attain paraffin sections of about 7 micron thickness, (Mukharji, 1990). The sections had been stained with the aid of Mercury bromophenol blue stain, protein content material of the tissues stained blue in color (Bonhag, 1955).

\section{Results and Discussion}

Demonstration of protein concentration in intestinal tissue of infected and non-infectedbroiler chicks from treated and non-treated groups are studied by using histochemical techniques. The presence of protein concentration demonstrated by variable traces like minimum, medium and maximum. The amount of protein content in different region of the intestinal tissue are variable, it is due to the parasitic infection.During the experiments the homoeopathic medicine Mercurius corrosivus $1 \mathrm{M}$ potency has shown the variation in protein concentration demonstrated by weak or strong staining reaction in the intestinal tissue.During the experiment results of the present investigation by using histochemical techniques shows that the group A (NHC) non-infected healthy chicks, normal intestinal tissue demonstrate more amount of protein concentration. Muscular layer, submucosa and mucosa of intestinal tissue have protein content but particularly in the glandular tissue shows the high traces of protein content (Fig 1). According to the experimental schedule on the day 5 th of the period of post infection the intestinal tissue of group B (INC) infected non-treated chicks shows that, the different region of the intestinal tissue observed different traces of the concentration of protein.

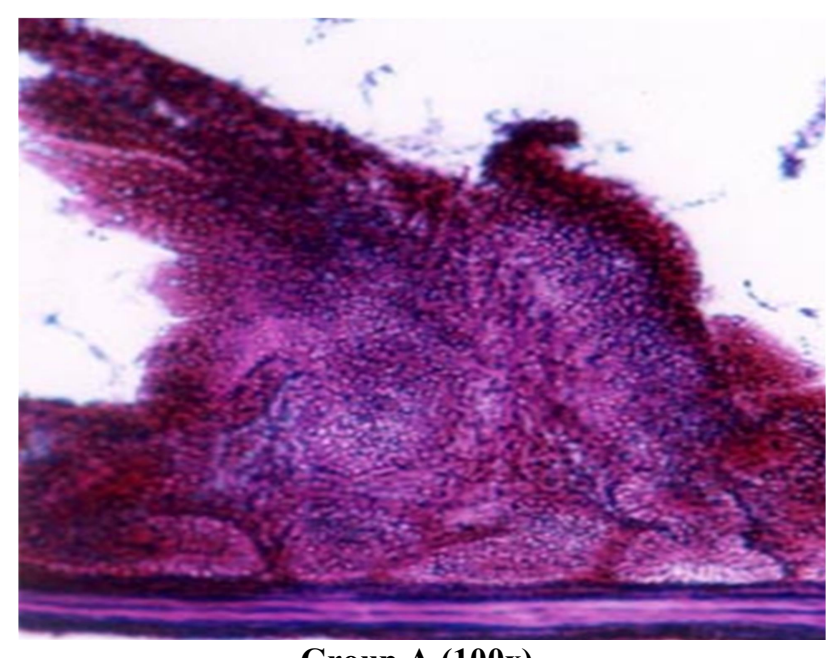

Group A (100x)

Fig 1. Group A (NHC)* no infected healthy chicks showing the distribution of protein content in the transverse section of normal intestine.

*Group: A-NHC: Noninfected healthy chicks

Submucosal layer, internal epithelium and villous tissue of intestine shows high concentration of protein content.The intestinal tissue of group $\mathrm{C}$ (IAC) infected and Amprolium treated chick's shows that the muscular layer and intestinal mucosa presence of high amount of protein concentration. The region of the intestinal tissue particularly villi shows the amount of protein concentration is moderate as compare to the other region that is muscular layer of the intestinal tissue. The intestinal tissue of group D (IMC) infected and Mercurius corrosivus treated chicks. The post infection period of this experimental group particularly the chicks were coccidiosis infected and treated with homoeopathic medicine Mercurius corrosivus 1M potency shows that the different region of the intestinal tissue have variation in the protein content. The protein content is maximum in the intestinal tissue particularly the muscular layer, mucosa and submucosa, medium amount in connective tissue while minimum amount of protein concentration in the villous epithelial cells (Fig 2). 

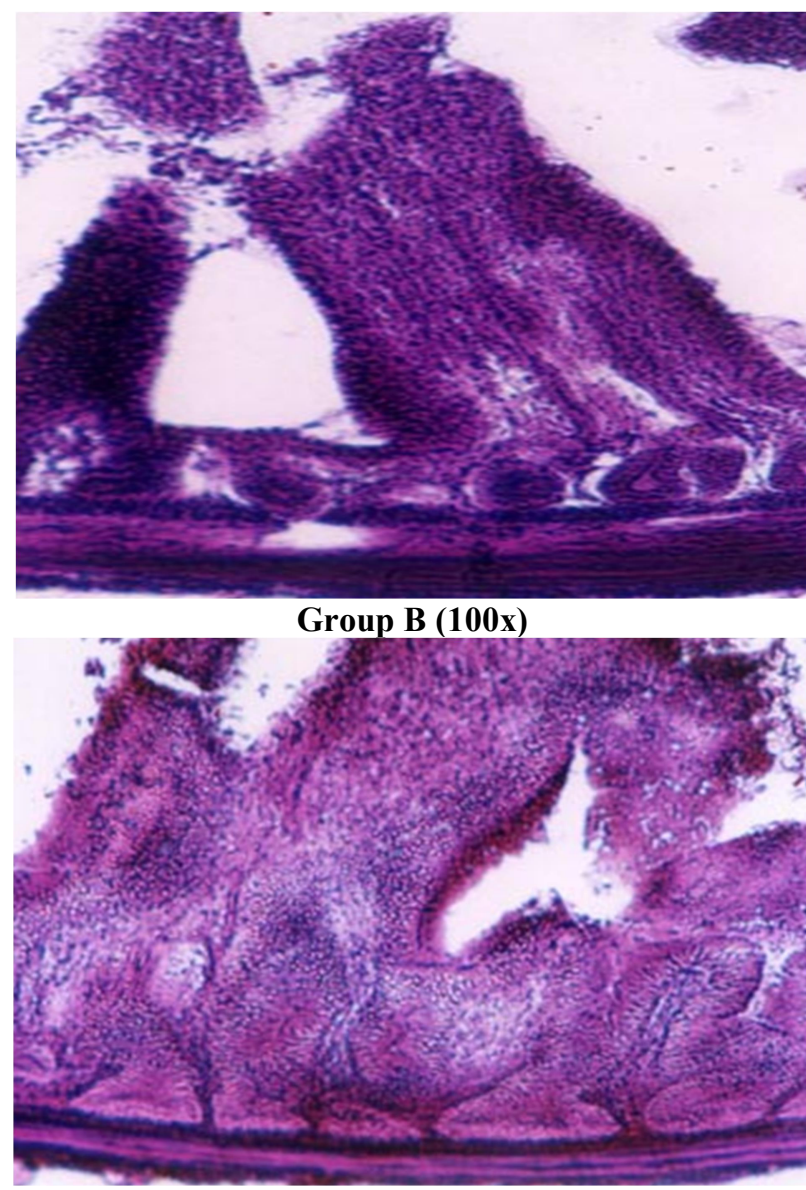

Group C (100x)

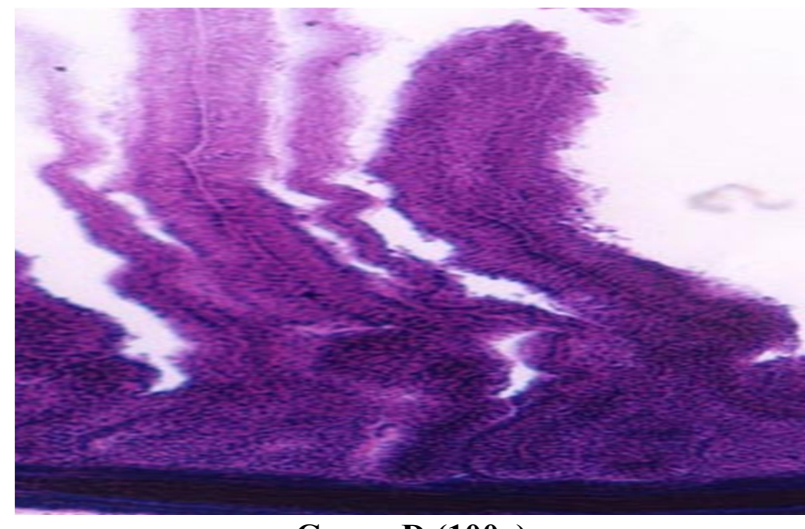

Group D (100x)

Fig 2. Group B (INC)**, group C (IAC)*** and group D (IMC)**** showing the distribution of protein content in the transverse section of the intestine on $5^{\text {th }}$ post infection day.

**Group : B-INC: Infected nontreated chicks ***Group : C-IAC: Infected and Amprolium treated chicks ****Group : D-IMC: Infected and Mercurius corrosivus treated chicks

\section{Conclusion}

From the above observations the present study concluded that the infection of coccidiosis of broilers chicks caused by giving the dose of $E$. tenella pathogen destruct the entire life process of the chicks. The severity of the disease is evaluated on the basis of histochemical changes occurred in the intestinal tissue due to E.tenella infection. It can be concluded that the intestinal tissue from all groups have the amount of protein in the form of different staining reaction. The protein concentration demonstrated by minimum, medium and maximum traces of staining reaction. It is either weak or heavy reaction with the staining but the protein content is maximum in the parasitic stages showing the protein utilization from the intestinal tissue. The present study contribute to understanding the protein concentration in intestinal tissue of coccidiosis infected broiler chicks treated with Mercurius corrosivus by using histochemical techniques. Changes occurred in various tissues of the chicks due to the disease resulting loss to the health of chicks ultimately loss to the farmers, so the broiler chicks should be under anticoccidial treatment by using homoeopathic medicine Mercurius corrosivus.

\section{Acknowledgement}

The worker is grateful to the Professor and Head, Department of Zoology, Dr. Babasaheb Ambedkar Marathwada University, Aurangabad (M.S.) India; Dr. V P Vadlamudi and Dr. N. M. Degloorkar from College of Veterinary and Animal Sciences, Marathwada Agricultural University Parbhani (M.S.) India, for providing laboratory and library centers, Dr. S. M. Desarda, Principal and Director, Drug proving unit, D. K. M. M. Homoeopathic Medical College, Guruganeshnagar, Aurangabad (M.S.) India for offering the homoeopathic medicinal drug and additionally grateful to the Principal, Yeshwantrao Chavan College of Arts, Commerce and Science, Sillod, Dist. Aurangabad (M.S.) India.

\section{References}

Al-Saffar, F. J., Eyhab, R. M. and Al-Samawy, 2016. Histomorphological and histochemical study of the small intestine of the striated scope owls (OtusScorsBrucei). Singapore Journal of Chemical Biology, 5: 1-10. 
Bonhag, P. F. 1955. Histochemical studies of the ovarian nurse tissue and oocyte of the milkweed bug, oncopeltus fasciatus (Dallas). Journal of Morphology, 96 (3): 381439.

Chaudhuri, N. M. 1990. A Study on Materia Medica, Publisher: B. Jain Publishers Pvt. Ltd., New Delhi.

Day Christhoper, 1988. The homeopathic treatment of small animals principles and practice. B. Jain Publishers (Pvt.) Ltd. New Delhi.

Farrington, E. A. 1989. Clinical Materia Medica, XIV Edition Revised and enlarged by Harrey Farrington, B. Jain Publishers Pvt. Ltd., New Delhi, 55.

Gill, B. S. and Bajwa, R. S. 1979. Drug resistance in field isolates of chicken coccidia from Punjab State. Indian Journal of Parasitology, 3: 131-134.

Hodges, R. D. 1974. The Histology of the Fowl, Academic Press, Edition.

Madrewar, B. P. 1996. Therapeutics of Veterinary Homoeopathy, B. Jain Publishers (P) Ltd. New Delhi.

Mukharji, K. L. 1990. Medical Laboratory Technology Edition IP 1138 Tata Mcgrawhill publishing Co. Ltd. New Delhi.
Naveen, P. K. 2005. The relevance of homoeopathy in veterinary therapeutics and safe animal food production, proceedings of National seminar on Application of homoeopathy in birds, fishes, plants, soil, and environment held at Thrissur, Kerla.

Narahari, D. 1996. Commercial broiler production. Emkay Publications, Delhi.

Pellerdy, L. P., 1974. Coccidia and coccidiosis, Verlagpaulparey, No $2^{\text {nd }}$ edition, pp. 959.

Singh, J., Bajwa, R. S. and Gill, B. S. 1982. Effect of druges against coccidial infection of chicken and the resultant immunity. Indian Journal of Parasitology, 6: 183-190.

Singh, U. B, and Sulochana, S. C. 1997. Handbook of Histological and Histochemical techniques Edition II, pp. 39-41. Premier Publishing House, S-1-800, 1st floor, Kothi, Hyderabad-95.

Williams, R. B., Carlyle, W. W., Bond, W. W., Brown; D. R. 1999. The efficacy and economic benefits of paracox, a live attenuated anticoccidial vaccine, in commercial trials with standard broiler chickens in the United Kingdom. International Journal for parasitology oxford, 29: 341355. 